Journal of Humanities and Social Sciences Studies (JHSSS)

ISSN: 2663-7197

DOI: 10.32996/jhsss

Journal Homepage: www.al-kindipublisher.com/index.php/jhsss

\title{
A Study of University Students' Communication Behavior in Social Media from Theory of Uses and Gratification
}

\author{
Nurwahida Alimuddin ${ }^{1} \square$ Ibrahim Latepo ${ }^{2}$ \\ 12 Universitas Islam Negeri (UIN) Datokarama Palu, Indonesia
}

$\square$ Corresponding Author: Wahida Alimuddin, E-mail: nurwahida@iainpalu.ac.id

\begin{tabular}{|c|c|}
\hline ARTICLE INFORMATION & ABSTRACT \\
\hline $\begin{array}{l}\text { Received: } 17 \text { October } 2021 \\
\text { Accepted: } 05 \text { November } 2021 \\
\text { Published: } 30 \text { November } 2021 \\
\text { DoI: } 10.32996 / \text { jhsss.2021.1.4.11 } \\
\end{array}$ & $\begin{array}{l}\text { University students have intensively used social media in their daily life. The students } \\
\text { use social media for social, education, and interaction purposes. Some studies found } \\
\text { that students also use social media for psychological relief benefits such as building } \\
\text { happiness through making friends and finding entertainment. However, limited studies } \\
\text { have been conducted to find out variables that affect psychological needs in social }\end{array}$ \\
\hline $\begin{array}{l}\text { University students, } \\
\text { communication, behavior, social } \\
\text { media, uses and gratification } \\
\text { theory }\end{array}$ & $\begin{array}{l}\text { media use. This study, therefore, aims to find out variables that affect university } \\
\text { students' psychological needs in social media use. This study used a quantitative } \\
\text { method with a survey approach. Samples were eighty students who were purposively } \\
\text { recruited from four faculties. This study shows that information search, social } \\
\text { interaction, entertainment, narcissism, and attention seekers behavior have } \\
\text { significantly influenced the students' motivation to fulfill psychological needs in social } \\
\text { media use. Personal identity-building did not affect the students' use of social media } \\
\text { in fulfilling their psychological needs. The students might be focused on social identity } \\
\text { rather than personal identity building. We concluded that social media had become a } \\
\text { new source for university students to find psychological relief and well-being. }\end{array}$ \\
\hline
\end{tabular}

\section{Introduction}

Social media has changed the nature and scope of the way humans communicate today. Online social networks allow users to express their identities, build, expand, and maintain their social networks (Ellison et al., 2007). For example, Facebook, which has more than 1.2 billion users, has allowed its users to interact every day and has increased 22 percent of users every year. Facebook is one of the most widely used social media besides other social media platforms such as Instagram, Youtube, Twitter, Linkedln, etc. For this study, social media is defined as an electronic platform that allows users to create profiles within a restricted system, to maintain a list of other users to share content, view, and browse their list of connections online (Boyd \& Ellison, 2008). Hence, a social media site is a World Wide web page wherein a particular site facilitates interaction between its various users.

Humans have been forming social bonds for a long time conventionally. However, social ties in online social networks are fundamentally different from conventional social networks. The differences include online social networks that can form greater social bonds than conventional social networks (Haythornthwaite, 2005). Then social media users have fewer cues to form impressions about other people in their network, so they are not as attached to norms as in conventional social ties (Paluck \& Shepherd, 2012). Furthermore, users carefully manage self-profiles to highlight positive attributes and present themselves more ideally. The more rapid development of communication and information technology has also driven the rapid growth of social media users. For example, the number of internet users in Indonesia grows 10.12 percent every year. The number of Indonesian Internet users in 2019 was 171 million people or about 65 percent of Indonesia's total population of 264 million people (APJII, 2019). Meanwhile, Indonesia's number of active social media users increased by 20 percent in 2019, reaching 150 million users (Pratnyawan, 2019).

Copyright: (C) 2021 the Author(s). This article is an open access article distributed under the terms and conditions of the Creative Commons Attribution (CC-BY) 4.0 license (https://creativecommons.org/licenses/by/4.0/). Published by Al-Kindi Centre for Research and Development, London, United Kingdom. 
Indonesia is ranked as the 4th largest Facebook user after the USA, Brazil, and India (Kusumasondjaja, 2018). The high number of Facebook users was caused by the rapid development of telecommunications and information technology in Indonesia. Information technology makes distance no longer a problem in communication. Indonesia is also ranked as the 5th largest Twitter user in the world after the USA, Brazil, Japan, and England (Sembiring, 2018). The use of social media had an influence in realworld life on adolescents both socially and psychologically. Socially, teenagers use social networking sites as a medium of friendship, exchange information, broaden their horizons, even online businesses that can provide material benefits (Selviana, 2016). While psychologically, the use of social media can provide happiness for its users because of ease of use and more comfortable.

As a result, the development of today's young generation's communication behavior has changed significantly after social media. The young generation spends more time communicating through social media. The young generation uses social media to fulfill their psychological and social needs, such as getting information, doing business, joining a group, making friends, or even just for fun to fill spare time.

However, research related to the behavior of university students in using social media to fulfill their psychological needs has not been widely carried out. Whereas understanding the younger generation's behavior in using social media can contribute to a better understanding of the students' behavior on social media use and improve academia and practitioners' insights. For this reason, this study aims to increase practitioners' and academics' understanding of the younger generation's behavior, especially students, in using social media. This research also aims to provide information to practitioners, especially the business world, so that they can be used for business purposes. With the research that uses the uses and gratification theory, it will be able to contribute to the development of theories in the field of using social media.

\section{Literature Review}

\subsection{Communication on Social Media}

Communicating through social media has been common since the emergence of various social media applications. Communication through social media is often referred to as collaborative and participatory communication (DePaula et al., 2018). Collaborative communication means that communication involves many people through online networks built as a result of friendship (Agarwal \& Bharadwaj, 2013). At the same time, participatory communication is communication that occurs as a result of social media users participating in the communication process both between individuals and in groups through social media.

The word communication has been interpreted differently according to the perception of each individual. In this study, communication is defined as something that is used to show something else based on the agreement of a group of people (Donnellon et al., 1986). Therefore, the word communication here is also understood as a human process responding to the symbolic behavior of other people (Bucci, 2001). Language, words, gestures, signs are part of the symbols used by humans in communication to define something or convey something to someone else. And how humans use language, words, gestures, and signs is learned in communication science, including the implications that arise from the use of various symbols.

Human communication runs at various levels of communication. Communication starts from the intrapersonal, interpersonal, group, public communication and to mass communication. Mass communication is the largest level of communication, where the scope of the communication target involves many people. Mass communication consists of messages transmitted to a large and widespread target audience, using newspapers, magazines, television, radio, and so on (Brinn et al., 2012). It can be said, the media used in conveying messages in mass communication are referred to as mass media.

The communication level consists of intrapersonal, interpersonal, group, public, and mass communication. Within the communication 2.0 context, each level of communication has its own characteristics. Communication 2.0 is understood as the development of new media brought the consequences of shifts and changes in mass communication theories (Napoli, 2010). The characteristics of the media that have been known so far have merged into the new media (Nurdin et al., 2013). This is because of the formation of mass-self communication. In the new media, there is a combination of interpersonal communication with mass communication.

When the communication reaches a global audience, it is called mass communication. However, it is called interpersonal communication when the messages are created, directed, and consumed personally (Berger). Communication does not occur interactively in social media if the party is not invited to communicate from the existing conversation. The exchange of information does not occur when the owner of the social media pages only communicates in one direction. However, as soon as other parties respond to what someone wrote and interaction occurs, interpersonal communication also occurs. For many people, online communication facilitates the formation of close interpersonal relationships. Through online communication, each individual 
involved tends to be more courageous in expressing his opinion and opening himself up to be known by others. Communication in social

\subsection{Teori Uses and Gratifications}

The basic concept of the Uses and Gratifications theory is that the main problem in using media is not how the media becomes a means of communication for users but how the media can meet users' personal and social needs. Users are considered to be actively using the media to fulfill their personal needs and have certain goals. A number of studies in the field of communication have focused on the use of media to obtain one's psychological gratifications. From the results of this study, the uses and gratification concept emerged. Most of the behavior of media users is then explained through the fulfillment of individual needs and interests (Ardianto et al., 2004). In other words, individual needs in using media in communication are the basis for the emergence of the uses and gratification theory.

The gratification and uses theory was first introduced by Elihu Katz, which emphasizes what the media does to users (what media do to people) and what users do to the media (what people do to media) in fulfilling their psychological needs. Media users actively use media to fulfill their mental satisfaction and desires. Thus, the uses and gratifications theory explains the media as a means of communication and a means of fulfilling its users' personal and social needs. (Effendy, 2017).

The uses and the gratification theory in this study, three main variables are considered to influence communication behavior in using social media. These variables include the need for information, interaction with other people, and the desire to get entertainment. These three variables are considered very easy to obtain through social media owned by each user. For example, the need for entertainment will be available on social media because other users will always share entertaining information. Then a variety of useful information is also always shared at any time by various social media users.

\subsection{Theoretical Construct}

This study uses six variables to determine students' behavior at Universities Islam Negeri Datokarama Palu in using social media. The leading theory in this research is the uses and gratification theory (Whiting \& Williams, 2013). The uses and gratification theory is often used to determine mass psychology in the field of communication. However, in this study, we use the uses and gratification theory to determine the psychological behavior of students in using social media, as previously used by Liu, Min, and Han. (2020) and Ray, Dhir, Bala and Kaur (2019). In this study, a number of variables have also been added to enrich the uses and gratification theory. The added variables include narcissism (Andreassen et al., 2017; McCain \& Campbell, 2018) and attention seekers (Hodis et al., 2015; Khamis et al., 2017). Narcissism and attention-seeking behavior on social media is common among the younger generation. For this reason, this study will test the theory on students at the narcissism and attention-seeking behavior on social media is common among the younger generation. For this reason, this study will test the theory on students at Universitas Islam Negeri Datokarama Palu.

In the context of social media, each individual is considered a network node that connects with other individuals (Scheepers et al., 2014). The relationship is carried out through word-of-mouth interaction between them on social media. These social media users have the opportunity to connect, communicate, share content, and create a community in an online network. Researchers call this defining it as a mechanism for democratizing information, which turns people into content recipients and producers. (Maiz et al., 2016). Social media users feel comfortable interacting through Facebook (Moretta \& Buodo, 2018). As a result, these interactions become a means of fulfilling user psychology which is carried out through fulfilling knowledge when interacting on social media, making professional friends, sharing information with each other, and contacting other new friends.

Narcissism is one of the behaviors that can occur on social media. Narcissism is excessive desire or admiration for one's own physical appearance (Moon et al., 2016). Narcissism can also be defined as "relatively stable individual differences consisting of greatness, self-love, and an inflated self-view (Mathieu, 2013). Therefore, indicators of narcissism can include behavior like sending pictures of themselves on social media, taking selfies, and being curious about other people's comments about them.

Social media users also like to seek attention from other people in their network. Attention-seeking behavior is an activity of showing oneself excessively to others on social media (Taylor \& Strutton, 2016). Attention-seeking indicators include liking when other people know what they are doing on social media and like to post things on social media so that other people notice it. Also, social media users tend to build their online identities. The identities are considered social identities oriented towards seeking attention from their online communities (Pan et al., 2017). The identities are often manifested in a dedicated individual in a certain area, users' pop culture, fans, motivators, and information seekers (Jimmy, 2013). Through social media, young users can more actively and diversely assert their identity. The action, then, reinforces identification, liking, and social interaction with friends. 
The ability to have wider social interaction is also a prominent benefit for social media users. High levels of interaction through social media can lead to strong online social cohesion (Fischer \& Reuber, 2011). Information sharing is a way to make social interaction, and it should be apparent in social interactions within the online space (Boudewyns et al., 2015). When social media users make more interaction, they will expand their relationship with wider online communities. As such, more friends are made, and it will increase emotional happiness and social well-being.

Entertainments are things that are easy to access on social media because more people share them freely. The types of entertainment available on social media can be in games, movies, and songs, which allow users to enjoy them as audiences (Cunningham \& Craig, 2017). When users enjoy the entertainment together, they may form a new group or community that has a similar concern called communitainment. The communititainment is considered community-driven communication through selfrepresentation and self-disclosure in social media use to create well-being in social media networks (Stollfuß, 2020).

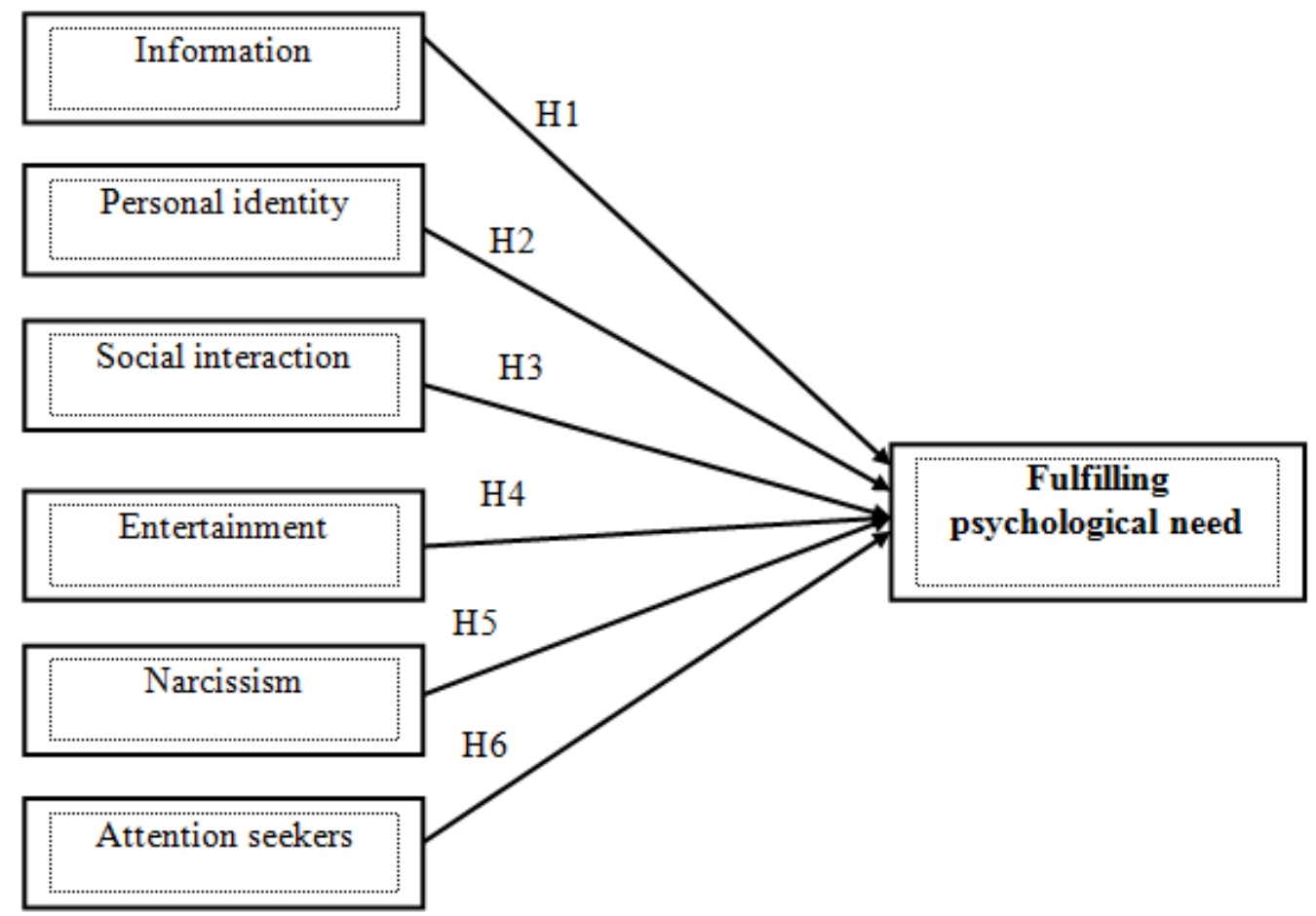

\section{Methodology}

This study was conducted using a quantitative paradigm with a survey approach (Miller, 2001; Nurdin, Azizah, et al., 2020). The population of this study is the students of Universitas Islam Negeri Datokarama Palu, Indonesia, from four faculties. There are about 65000 students across the four faculties. However, through quota sampling (Nurdin, Musyawarah, et al., 2020; Yang \& Banamah, 2014), we randomly selected twenty students from each faculty. As such, 80 students were used as the sample, and they were given five scale questionnaires. All the questionnaires were distributed directly to the students, and they were returned completely.

The five Likert-scale questionnaires were used based on the assumption that they were a sensitive and robust measure (Ali, 1987; Latepo et al., 2021). In addition, the five Likert scales are considered more likely to reflect a respondent's real subjective evaluation of a usability questionnaire item in a quantitative measurement (Khaldun, 1996; Nurdin et al., 2021). The questionnaires were divided into seven sections according to the variables determined in the theoretical construct. Each variable consisted of five questions, except the $Y$ variable consisted of ten questions. The results of the survey were calculated using SPSS (Marr-Lyon et al., 2012).

\section{Results and Discussion}

\subsection{Respondents' Demographic}

Some demographic questions were asked in the survey distributed to the students of the university to understand their sex and behavior in using social media. The result of the survey is presented in table 1 below: 
Table 1: Students' sex and characteristics in using social media

\begin{tabular}{|c|c|c|c|c|c|c|}
\hline No & Questions & \multicolumn{5}{|l|}{ Responses } \\
\hline \multirow{2}{*}{1} & \multirow{2}{*}{ Sex } & \multicolumn{3}{|l|}{ Men } & \multicolumn{2}{|c|}{63} \\
\hline & & \multicolumn{2}{|l|}{ Women } & \multicolumn{3}{|l|}{17} \\
\hline \multirow{2}{*}{2} & \multirow{2}{*}{ Do you use social media? } & \multicolumn{3}{|l|}{ Yes } & \multicolumn{2}{|l|}{ No } \\
\hline & & \multicolumn{3}{|l|}{$100 \%$} & \multicolumn{2}{|l|}{-} \\
\hline \multirow[b]{2}{*}{3} & \multirow{2}{*}{$\begin{array}{l}\text { How many hours do you } \\
\text { use social media a day? }\end{array}$} & $<1$ hour & 1 hour & 2 hour & 3 hours & $>4$ hours \\
\hline & & $22.2 \%$ & $31.1 \%$ & $15.6 \%$ & $13.3 \%$ & $17.8 \%$ \\
\hline \multirow{2}{*}{4} & \multirow{2}{*}{$\begin{array}{l}\text { How do you access social } \\
\text { media? }\end{array}$} & $\begin{array}{l}\text { Using } \\
\text { Smartphone }\end{array}$ & $\begin{array}{l}\text { Using } \\
\text { laptop }\end{array}$ & $\begin{array}{l}\text { Using } \\
\text { desktop }\end{array}$ & \multicolumn{2}{|c|}{$\begin{array}{l}\text { Using Smartphone } \\
\text { and laptop }\end{array}$} \\
\hline & & $80.0 \%$ & $6.7 \%$ & - & \multicolumn{2}{|l|}{$13.3 \%$} \\
\hline \multirow{2}{*}{5} & \multirow{2}{*}{$\begin{array}{l}\text { Where do you use social } \\
\text { media }\end{array}$} & \multicolumn{2}{|l|}{ On-campus } & At home & \multicolumn{2}{|c|}{ Both } \\
\hline & & \multicolumn{2}{|l|}{$6.7 \%$} & \multicolumn{2}{|l|}{$33.3 \%$} & $60.0 \%$ \\
\hline
\end{tabular}

Data from the table above showed that most of the respondents were men, with a total of 63 students and 17 respondents being women. Regarding their behavior in using social media, it was found that most of the respondents used social media between one to four hours each day using smartphones devices. In addition, the majority of the respondents accessed social media while they were on campus. High-intensity use of social media reflects the high psychological bond between students and social media (Kim \& Kim, 2017). The results might prove that social media usage positively affects university students' communication networks in their everyday lives.

\subsection{Validity Test}

All items in the questionnaires of this study were tested before they were used to prove their validity. The validity test found that all the questions administered in this study were valid and reliable. Therefore, all of the questions were used for further study and analysis. The results of the validity test of each question are presented in table 2 below:

Table 2. The Results of Validity Test

\begin{tabular}{|c|c|c|c|c|}
\hline Variable & Questions & $\begin{array}{l}\text { Corrected Item } \\
\text { Questions Total } \\
\text { Correlation }\end{array}$ & R Table & Validity \\
\hline \multirow{5}{*}{ Information Search } & $\begin{array}{l}\text { Finding information related to society and } \\
\text { the Islamic world }\end{array}$ &, 402 & 0,257 & VALID \\
\hline & $\begin{array}{l}\text { Finding practical information related to my } \\
\text { studies }\end{array}$ & 309 & 0,257 & VALID \\
\hline & $\begin{array}{l}\text { Conduct self-learning using material from } \\
\text { social media }\end{array}$ &, 575 & 0,257 & VALID \\
\hline & $\begin{array}{l}\text { Fulfilling my knowledge with information } \\
\text { from social media }\end{array}$ &, 532 & 0,257 & VALID \\
\hline & $\begin{array}{l}\text { I feel comfortable with information from } \\
\text { social media }\end{array}$ & 624 & 0,257 & VALID \\
\hline \multirow[t]{4}{*}{ Personal Identity } & I search any information from social media &, 550 & 0,257 & VALID \\
\hline & $\begin{array}{l}\text { I built my new online identity on the social } \\
\text { media }\end{array}$ & ,389 & 0,257 & VALID \\
\hline & Social media give me new looks &, 580 & 0,257 & VALID \\
\hline & I show my new hobbies on social media & ,389 & 0,257 & VALID \\
\hline
\end{tabular}




\begin{tabular}{|c|c|c|c|c|}
\hline & I often promote my activities on social media &, 580 & 0,257 & VALID \\
\hline \multirow{5}{*}{ Social interaction } & Making friends on social media is fun & 278 & 0,257 & VALID \\
\hline & I am happy when my friends like my postings & 663 & 0,257 & VALID \\
\hline & $\begin{array}{l}\text { I often invite my friends on social media to } \\
\text { comment on my postings }\end{array}$ & ,568 & 0,257 & VALID \\
\hline & $\begin{array}{l}\text { I quickly accepted new friends request on my } \\
\text { Facebook }\end{array}$ & 350 & 0,257 & VALID \\
\hline & I often look for new friends on social media &, 518 & 0,257 & VALID \\
\hline \multirow[t]{5}{*}{ Entertainments } & Social media can entertain me & 305 & 0,257 & VALID \\
\hline & $\begin{array}{l}\text { I often access songs shared by my friends on } \\
\text { social media }\end{array}$ & 314 & 0,257 & VALID \\
\hline & $\begin{array}{l}\text { I often play online games on my Facebook } \\
\text { with my friends }\end{array}$ & 375 & 0,257 & VALID \\
\hline & I often watch movies shared on social media &, 532 & 0,257 & VALID \\
\hline & $\begin{array}{l}\text { I join with communititaiment on social } \\
\text { media }\end{array}$ & 544 & 0,257 & VALID \\
\hline \multirow{5}{*}{ Narcissism } & I often post my photos on social media &, 530 & 0,257 & VALID \\
\hline & I often take selfies on social media & 324 & 0,257 & VALID \\
\hline & I love posting photos on social media & 436 & 0,257 & VALID \\
\hline & $\begin{array}{l}\text { I often wonder if people see the photos I } \\
\text { post on social media }\end{array}$ & ,701 & 0,257 & VALID \\
\hline & $\begin{array}{l}\text { I'm happy to have a lot of followers on social } \\
\text { media }\end{array}$ & 669 & 0,257 & VALID \\
\hline \multirow[t]{5}{*}{ Attention seekers } & $\begin{array}{l}\text { I'm happy when other people know what I } \\
\text { do on social media }\end{array}$ & ,695 & 0,257 & VALID \\
\hline & $\begin{array}{l}\text { I'm going to post something on Facebook } \\
\text { that catches the attention of my friends }\end{array}$ & 642 & 0,257 & VALID \\
\hline & $\begin{array}{l}\text { I love it when my friends on Facebook } \\
\text { comment on my posts }\end{array}$ & 315 & 0,257 & VALID \\
\hline & $\begin{array}{l}\text { I'm happy when friends on social media } \\
\text { comment on my posts }\end{array}$ & 321 & 0,257 & VALID \\
\hline & & 282 & 0,257 & VALID \\
\hline \multirow{10}{*}{$\begin{array}{l}\text { Fulfilling } \\
\text { psychological need }\end{array}$} & $\begin{array}{l}\text { I share entertainment content on social } \\
\text { media }\end{array}$ & 561 & 0,257 & VALID \\
\hline & $\begin{array}{l}\text { I like to make interaction with new persons } \\
\text { on social media }\end{array}$ & 609 & 0,257 & VALID \\
\hline & $\begin{array}{l}\text { I share information with my friends on social } \\
\text { media }\end{array}$ & 487 & 0,257 & VALID \\
\hline & $\begin{array}{l}\text { I download music or movies from my friends' } \\
\text { social media homepages }\end{array}$ & 362 & 0,257 & VALID \\
\hline & $\begin{array}{l}\text { I am happy to get information from my } \\
\text { people on social media }\end{array}$ & 663 & 0,257 & VALID \\
\hline & $\begin{array}{l}\text { I am happy when someone on social media } \\
\text { contacts me }\end{array}$ & 270 & 0,257 & VALID \\
\hline & $\begin{array}{l}\text { I like to accept a friend request on social } \\
\text { media }\end{array}$ & 698 & 0,257 & VALID \\
\hline & $\begin{array}{l}\text { I like to share my study material with my } \\
\text { friends on social media }\end{array}$ & ,545 & 0,257 & VALID \\
\hline & $\begin{array}{l}\text { I use the information on social media to } \\
\text { make further interaction with someone on } \\
\text { social media }\end{array}$ & 612 & 0,257 & VALID \\
\hline & I like to show my activities on social media & ,788 & 0,257 & VALID \\
\hline
\end{tabular}


The validity test result on the table above shows that each question has an $r$ value higher than the $r$ table $(0,257)$, showing positive results. As such, all questions are valid and can be used in this study. The reliability test of each variable is depicted in table 3 below.

Table 3. Variables Reliability Test Results

\begin{tabular}{|c|c|c|c|}
\hline Variables & $\begin{array}{l}\text { Reliabilities } \\
\text { Coefficient }\end{array}$ & $\begin{array}{l}\text { Cronbach } \\
\text { Alpha }\end{array}$ & Reliable \\
\hline \multicolumn{4}{|l|}{$\mathbf{x}$} \\
\hline Information Search & 5 items & 0,791 & Reliable \\
\hline Personal Identity & 5 items & $0 / 790$ & Reliable \\
\hline Social interaction & 5 items & 0,780 & Reliable \\
\hline Entertainments & 5 items & 0.781 & Reliable \\
\hline Narcissism & 5 items & 0,710 & Reliable \\
\hline Attention seekers & 5 items & 0.711 & Reliable \\
\hline \multicolumn{4}{|l|}{$\mathbf{Y}$} \\
\hline $\begin{array}{l}\text { Intention to use sharia } \\
\text { FinTech }\end{array}$ & 10 items & 0,690 & Reliable \\
\hline
\end{tabular}

The reliability test of the variable above shows that each variable has Alpha Cronbach higher than 0,6 . The results explain that all the variables (information search, personal identity, social interaction, entertainment, narcissism, and attention seekers) are reliable. We calculated multiple linear regressions based on the test results, which are presented in table 4 below.

Table 4. The Results of Multiple Linear Regression Coefficients

\begin{tabular}{|c|c|c|c|c|c|c|c|}
\hline \multirow[b]{2}{*}{ Model } & \multicolumn{2}{|c|}{$\begin{array}{l}\text { Unstandardized } \\
\text { Coefficients }\end{array}$} & \multirow{2}{*}{$\begin{array}{l}\text { Standardized } \\
\text { Coefficients } \\
\text { Beta } \\
\end{array}$} & \multirow[b]{2}{*}{$\mathrm{t}$} & \multirow[b]{2}{*}{ Sig. } & \multicolumn{2}{|c|}{ Collinearity Statistics } \\
\hline & B & Std. Error & & & & Tolerance & VIF \\
\hline $1 \quad$ (Constant) & $-1,681$ & 2,271 & &,- 740 & 461 & & \\
\hline $\mathrm{X} 1$ &, 449 &, 065 &, 528 & 6,911 &, 000 & 654 & 1,529 \\
\hline $\mathrm{X} 2$ &,- 034 &, 075 &,- 032 &,- 457 & 649 & ,769 & 1,300 \\
\hline X3 &, 457 &, 067 &, 536 & 6,976 &, 000 & ,665 & 1,564 \\
\hline $\mathrm{X} 4$ &, 564 & ,091 &, 468 & 6,986 &, 000 & 672 & 1,546 \\
\hline$\times 5$ &, 535 & ,087 &, 462 & 6.351 &, 000 & 623 & 1,536 \\
\hline X6 &, 574 & ,093 &, 454 & 6,157 &, 000 & ,702 & 1,424 \\
\hline
\end{tabular}

a. Dependent Variable: $Y$

The results of regression calculation show that the $t$ value of variable information search behavior (X1), social interaction (X3), entertainment (X4), narcissism (X5), and attention seekers behavior (X6) have a positive influence on fulfilling the psychological need in social media use. Meanwhile, variable personal identity-building behavior (X2) has no impact on intention to fulfill the psychological need in social media use. The result of hypotheses testing of variables is presented in the following figure 2. 


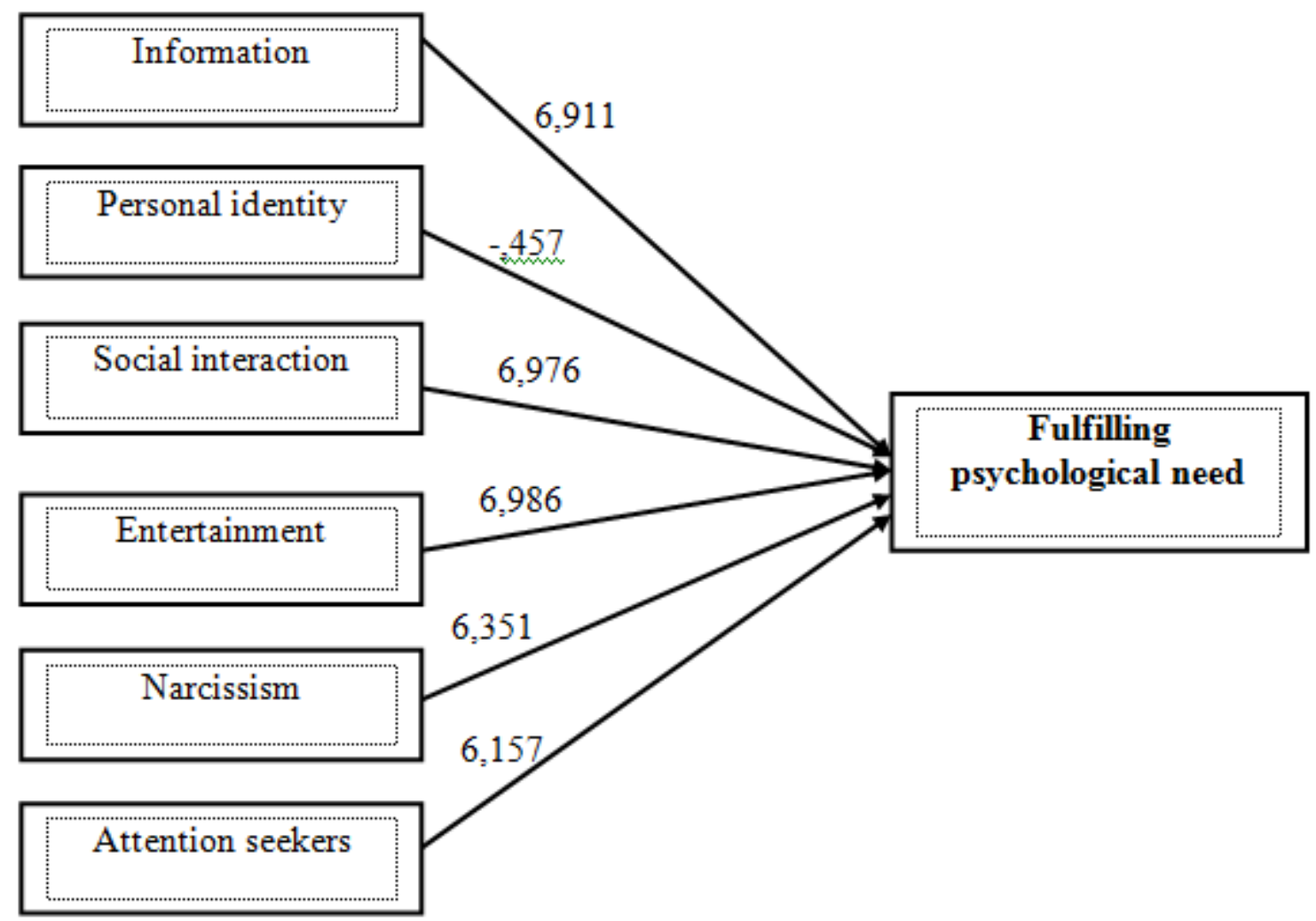

Figure 2. The Results of Hypothèses Test

\subsection{Discussion}

Information search behavior is a common phenomenon in social media usage. However, information search behavior has been found shaped by individual traits such as learning, perception, motivation, personality, and attitude (Luo et al., 2004). In this study, we found that students used social media to find information to support their study, and the information might increase their conformability in learning. Our study also confirms that social media has become a source of information for the student's learning success (Kim et al., 2011). Types of social media that can be used for information sources include Wikipedia, social networking, YouTube, and Blog.

In previous studies in offline contexts, social interaction has been found to play roles as a source of psychological well-being because it supports social cognition, social identity building, and social representations processes (Kashima et al., 2007). In the context of social media, social interaction is built through an online network across social media platforms that connect individuals and groups. Our study found that social media attributes have increased students' preference for online social interaction. Furthermore, the interaction is related to the students' need for psychological self-esteem (Kim, 2017; Rusli \& Nurdin, 2021). We suspect that social media might have positive or pro-social attitudes among the students and that online socializing, under specified conditions (Bessière et al., 2008).

Social interaction on social media is usually shown in the form of giving Likes, comments, or contacting others with reference to certain posts on social media. The activities can have effects on well-being because the activities are considered to "refer to the manner in which individuals benefit from each other on their encounters, interactions, empathy, or mutual support" (Stollfuß, 2020).

Adoption of entertainment on social media has been found in previous studies (e.g.Cunningham \& Craig, 2017; McDool et al., 2020). Social media entertainment is understood as the characteristics of a "social media user's entertainment experience." Social media users experience media entertainment as a form of media use that is enjoyed and experienced for the sake of enjoyment. Users who enjoy entertainment on social media can experience relief, pleasure, well-being, and self-efficacy (Stollfuß, 2020). In addition, social media has been found as a source of entertainment providers. This has a substantial impact on users 'sustainable intention to continue using a particular social media site. One major reason for using social media entertainment services is to have fun and spend time pleasurably by participating in activities such as product discussions, chatting, and seeking business 
opportunities. As such, entertainment on social media is an important factor that promotes the sustainable use of social media. In our study, the feeling of enjoyment has significantly influenced the behavior of social media entertainment (Abbas Naqvi et al., 2020).

Narcissism is the behavior of the users that is reflected in excessive desire or admiration for one's own physical appearance (Moon et al., 2016). As such, in this study, we found the students often post their own photos and do selfies on social media. The users, then, excessively admire their own photos and activities posted on social media. The activities are also related to the behavior to seek attention from their online friends because the users expect their online friends to like and give comments to every photo or activity posted on social media (Taylor \& Strutton, 2016). Therefore, the users feel happy when their friends provide comments on every photo or activity posted on their social media page. In addition, perceived happiness is experienced when users comment and upload content as well as when the contents are shared across social media networks (Khan, 2017).

However, personal identity building does not have an influence on fulfilling the psychological need. We suspect that the students who use social media prefer to build social identities rather than create personal identities. The social identities were built through collective interaction across their online social network (Fujita et al., 2018). Therefore, they may be more concerned about online social collectivity rather than on personal identity. Personal identity might benefit when constructed in an offline social interaction context because the interaction may occur in personal or small social groups. Meanwhile, in online social networks, the identities are constructed to benefit all actors in the online network.

\section{Conclusion}

The objective of this study was to show that the theory of uses and gratification can explain the student's behavior in the use of social media to fulfill a psychological need. The variables of information search, social interaction, entertainment, narcissism, and attention-seeking behavior significantly impact students' intention to fulfill a psychological need in social media use. However, the personal identity variable does not impact students' intention to fulfill the psychological need in social media use. Our study highlights an important point: the young generation has utilized social media to achieve happiness and psychological well-being. Our study increases practitioners' and academics' understanding of the younger generation's behavior, especially students, in using social media. Future studies should conduct another study in a broader context to find out how social media can create happiness and psychological well-being. Future studies might also need to determine why personal identity building has no intention to fulfill the psychological need in social media use.

Funding: This research was funded by Universitas Islam Negeri (UIN) Datokarama Palu, Indonesia, grant number 436 and The APC was also funded by Universitas Islam Negeri (UIN) Datokarama Palu.

Acknowledgments: We acknowledge that we received support from the Rector of UIN DK Palu

Conflicts of Interest: The authors declare no conflict of interest.

\section{References}

[1] Abbas-Naqvi, M. H., Jiang, Y., Miao, M., \& Naqvi, M. H. (2020). The effect of social influence, trust, and entertainment value on social media use Evidence from Pakistan. Cogent Business \& Management, 7(1), 1723825. https://doi.org/10.1080/23311975.2020.1723825

[2] Agarwal, V., \& Bharadwaj, K. K. (2013). A collaborative filtering framework for friends recommendation in social networks based on interaction intensity and adaptive user similarity. Social Network Analysis and Mining, 3(3), 359-379. https://doi.org/10.1007/s13278-012$0083-7$

[3] Ali, Y. (1987). Pengantar Ilmu Talawuf Pedoman Ilmu Jaya.

[4] Andreassen, C. S., Pallesen, S., \& Griffiths, M. D. (2017). The relationship between addictive use of social media, narcissism, and self-esteem: Findings from a large national survey. Addictive Behaviors, 64, 287-293. https://doi.org/https://doi.org/10.1016/j.addbeh.2016.03.006

[5] APJII. (2019). Jumlah Pengguna Internet di Indonesia Tembus 171 Juta Jiwa https://tekno.kompas.com/read/2019/05/16/03260037/apjiijumlah-pengguna-internet-di-indonesia-tembus-171-juta-jiwa

[6] Ardianto, E., Komala, L., \& Karlinah, S. (2004). Komunikasi Massa: Suatu Pengantar. Simbiosa Rekatama Media.

[7] Berger, C. R. Interpersonal Communication. In The International Encyclopedia of Communication. https://doi.org/https://doi.org/10.1002/9781405186407.wbieci077

[8] Bessière, K., Kiesler, S., Kraut, R., \& Boneva, B. S. (2008). EFFECTS OF INTERNET USE AND SOCIAL RESOURCES ON CHANGES IN DEPRESSION. Information, Communication \& Society, 11(1), 47-70. https://doi.org/10.1080/13691180701858851

[9] Boudewyns, V., Himelboim, I., Hansen, D. L., \& Southwell, B. G. (2015). Stigma's Effect on Social Interaction and Social Media Activity. Journal of Health Communication, 20(11), 1337-1345. https://doi.org/10.1080/10810730.2015.1018604

[10] Boyd, D. M., \& Ellison, N. B. (2008). Social Network Sites: Definition, History, and Scholarship. Journal of Computer-Mediated Communication, 13(1), 210-230. https://doi.org/10.1111/j.1083-6101.2007.00393.x 
[11] Brinn, M. P., Carson, K. V., Esterman, A. J., Chang, A. B., \& Smith, B. J. (2012). Cochrane Review: Mass media interventions for preventing smoking in young people. Evidence-Based Child Health: A Cochrane Review Journal, 7(1), 86-144. https://doi.org/https://doi.org/10.1002/ebch.1808

[12] Bucci, W. (2001). Pathways of Emotional Communication. Psychoanalytic Inquiry, 21(1), 40-70. https://doi.org/10.1080/07351692109348923

[13] Cunningham, S., \& Craig, D. (2017). Being 'really real' on YouTube: authenticity, community and brand culture in social media entertainment. Media International Australia, 164(1), 71-81. https://doi.org/10.1177/1329878x17709098

[14] DePaula, N., Dincelli, E., \& Harrison, T. M. (2018). Toward a typology of government social media communication: Democratic goals, symbolic acts, and self-presentation. Government Information Quarterly, 35(1), 98-108. https://doi.org/https://doi.org/10.1016/j.giq.2017.10.003

[15] Donnellon, A., Gray, B., \& Bougon, M. G. (1986). Communication, Meaning, and Organized Action. Administrative Science Quarterly, 31(1), 43-55. https://doi.org/10.2307/2392765

[16] Effendy, O. U. (2017). Ilmu Komunikasi Teori Dan Praktek. Rosda Karya.

[17] Ellison, N. B., Steinfield, C., \& Lampe, C. (2007). The Benefits of Facebook "Friends:" Social Capital and College Students' Use of Online Social Network Sites. Journal of Computer-Mediated Communication, 12(4), 1143-1168. https://doi.org/10.1111/j.1083-6101.2007.00367.x

[18] Fischer, E., \& Reuber, A. R. (2011). Social interaction via new social media: (How) can interactions on Twitter affect effectual thinking and behavior? Journal of Business Venturing, 26(1), 1-18. https://doi.org/https://doi.org/10.1016/j.jbusvent.2010.09.002

[19] Fujita, M., Harrigan, P., \& Soutar, G. N. (2018). CAPTURING AND CO-CREATING STUDENT EXPERIENCES IN SOCIAL MEDIA: A SOCIAL IDENTITY THEORY PERSPECTIVE. Journal of Marketing Theory and Practice, 26(1-2), 55-71. https://doi.org/10.1080/10696679.2017.1389245

[20] Haythornthwaite, C. (2005). Social networks and Internet connectivity effects. Information, Communication \& Society, 8(2), $125-147$. https://doi.org/10.1080/13691180500146185

[21] Hodis, M. A., Sriramachandramurthy, R., \& Sashittal, H. C. (2015). Interact with me on my terms: a four-segment Facebook engagement framework for marketers. Journal of Marketing Management, 31(11-12), 1255-1284. https://doi.org/10.1080/0267257X.2015.1012535

[22] Jimmy, S. (2013). Stepping into the (Social Media) Game: Building Athlete Identity via Twitter. In L. Rocci (Ed.), Handbook of Research on Technoself: Identity in a Technological Society (pp. 419-438). IGI Global. https://doi.org/10.4018/978-1-4666-2211-1.ch023

[23] Kashima, Y., Klein, O., \& Clark, A. E. (2007). Grounding: Sharing Information in Social Interaction. In Social communication. (pp. 27-77). Psychology Press.

[24] Khaldun, I. (1996). al-Muqaddimah Dar al-Fikr.

[25] Khamis, S., Ang, L., \& Welling, R. (2017). Self-branding, 'micro-celebrity and the rise of Social Media Influencers. Celebrity Studies, 8(2), 191208. https://doi.org/10.1080/19392397.2016.1218292

[26] Khan, M. L. (2017). Social media engagement: What motivates user participation and consumption on YouTube? Computers in Human Behavior, 66, 236-247. https://doi.org/https://doi.org/10.1016/j.chb.2016.09.024

[27] Kim, B., \& Kim, Y. (2017). College students' social media use and communication network heterogeneity: Implications for social capital and subjective well-being. Computers in Human Behavior, 73, 620-628. https://doi.org/https://doi.org/10.1016/j.chb.2017.03.033

[28] Kim, H. H.-s. (2017). The impact of online social networking on adolescent psychological well-being (WB): a population-level analysis of Korean school-aged children. International Journal of Adolescence and Youth, 22(3), 364-376. https://doi.org/10.1080/02673843.2016.1197135

[29] Kim, K.-S., Yoo-Lee, E., \& Joanna Sin, S.-C. (2011). Social media as information source: Undergraduates' use and evaluation behavior. Proceedings of the American Society for Information Science and Technology, 48(1), 1-3. https://doi.org/https://doi.org/10.1002/meet.2011.14504801283

[30] Kusumasondjaja, S. (2018). The roles of message appeals and orientation on social media brand communication effectiveness. Asia Pacific Journal of Marketing and Logistics, 30(4), 1135-1158. https://doi.org/10.1108/APJML-10-2017-0267

[31] Latepo, I., Suharto, S., \& Nurdin, N. (2021). Understanding Muslim Preaching Students' Use of Social Media. International Journal of International Relations, Media and Mass Communication Studies, 7(1), 52-66.

[32] Liu, X., Min, Q., \& Han, S. (2020). Understanding users' continuous content contribution behaviors on microblogs: an integrated perspective of uses and gratification theory and social influence theory. Behaviour \& Information Technology, 39(5), 525-543. https://doi.org/10.1080/0144929X.2019.1603326

[33] Luo, M., Feng, R., \& Cai, L. A. (2004). Information Search Behavior and Tourist Characteristics. Journal of Travel \& Tourism Marketing, 17(2-3), 15-25. https://doi.org/10.1300/J073v17n02_02

[34] Maiz, A., Arranz, N., \& Fdez. de Arroyabe, J. C. (2016). Factors affecting social interaction on social network sites: the Facebook case. Journal of Enterprise Information Management, 29(5), 630-649. https://doi.org/10.1108/JEIM-10-2014-0105

[35] Marr-Lyon, L. R., Gupchup, G. V., \& Anderson, J. R. (2012). An evaluation of the psychometric properties of the Purdue Pharmacist Directive Guidance Scale using SPSS and R software packages. Research in Social and Administrative Pharmacy, 8(2), 166-171. https://doi.org/https://doi.org/10.1016/j.sapharm.2011.01.001

[36] Mathieu, C. (2013). Personality and job satisfaction: The role of narcissism. Personality and Individual Differences, 55(6), 650-654. https://doi.org/https://doi.org/10.1016/j.paid.2013.05.012

[37] McCain, J. L., \& Campbell, K. (2018). Narcissism and social media use A meta-analytic review. Psychology of Popular Media Culture, 7(3), 308327.

[38] McDool, E., Powell, P., Roberts, J., \& Taylor, K. (2020). The internet and children's psychological wellbeing. Journal of Health Economics, 69, 102274. https://doi.org/https://doi.org/10.1016/j.jhealeco.2019.102274

[39] Miller, K. (2001). Quantitative Research Method in The New Handbook of Organizational Communication: Advances in Theory, Research, and Methods by Frederick M. Jablin and Linda L. Putnam (Editors), London: Sage Publications.

[40] Moon, J. H., Lee, E., Lee, J.-A., Choi, T. R., \& Sung, Y. (2016). The role of narcissism in self-promotion on Instagram. Personality and Individual Differences, 101, 22-25. https://doi.org/https://doi.org/10.1016/j.paid.2016.05.042 
[41] Moretta, T., \& Buodo, G. (2018). Modeling Problematic Facebook Use: Highlighting the role of mood regulation and preference for online social interaction. Addictive Behaviors, 87, 214-221. https://doi.org/https://doi.org/10.1016/j.addbeh.2018.07.014

[42] Napoli, P. M. (2010). Revisiting 'mass communication' and the 'work' of the audience in the new media environment. Media, Culture \& Society, 32(3), 505-516. https://doi.org/10.1177/0163443710361658

[43] Nurdin, N., Azizah, W. N., \& Rusli, R. (2020). Pengaruh Pengetahuan,Kemudahan dan Risiko Terhadap Minat Bertransaksi Menggunakan Finansial Technology (Fintech) Pada Mahasiswa Institut Agama Islam Negeri (IAIN) Palu Jurnal Ilmu Perbankan dan Keuangan Syariah, 2(2), 199-222. https://www.kompasiana.com/windaaryani/5df634fa097f3651e741f432/mengenal-ontologi-epistemologi-dan-aksiologi-dalamkehidupan-sehari-hari

[44] Nurdin, N., Musyawarah, I., Nurfitriani, N., \& Jalil, A. (2020). Pengaruh Pelayanan Mobile Banking Terhadap Kepuasan Nasabah (Studi Pada Mahasiswa Perbankan Syariah IAIN Palu) Jurnal Ilmu Perbankan dan Keuangan Syariah, 2(2), 87-104.

[45] Nurdin, N., Ningrum, R., Bachmid, S., \& Jalil, A. (2021). Pengaruh Manfaat, Kepercayaan dan Kemudahan Penggunaan Terhadap Minat Nasabah Menggunakan Mobile Banking di Bank Mega Syariah Cabang Palu Jurnal Ilmu Perbankan dan Keuangan Syariah, 3(1), $30-45$.

[46] Nurdin, N., Stockdale, R., \& Scheepers, H. (2013). The Use of Social Media to Gather Qualitative Data: A Case of Government E-Procurement Implementation and Use. 24th Australasian Conference on Information Systems (ACIS)

[47] Paluck, E. L., \& Shepherd, H. (2012). The salience of social referents: A field experiment on collective norms and harassment behavior in a school social network. journal of Personality and Social Psychology, 103(6), 899-915.

[48] Pan, Z., Lu, Y., Wang, B., \& Chau, P. Y. K. (2017). Who Do You Think You Are? Common and Differential Effects of Social Self-Identity on Social Media Usage. Journal of Management Information Systems, 34(1), 71-101. https://doi.org/10.1080/07421222.2017.1296747

[49] Pratnyawan, A. (2019). Pengguna Instagram dan Facebook Indonesia Terbesar ke-4 di Dunia https://www.suara.com/tekno/2019/06/19/133252/pengguna-instagram-dan-facebook-indonesia-terbesar-ke-4-di-dunia

[50] Ray, A., Dhir, A., Bala, P. K., \& Kaur, P. (2019). Why do people use food delivery apps (FDA)? A uses and gratification theory perspective. Journal of Retailing and Consumer Services, 51, 221-230. https://doi.org/https://doi.org/10.1016/j.jretconser.2019.05.025

[51] Rusli, R., \& Nurdin, N. (2021). Understanding Indonesia millennia Ulama online knowledge acquisition and use in daily fatwa making habits. Education and Information Technologies. https://doi.org/10.1007/s10639-021-10779-7

[52] Scheepers, H., Scheepers, R., Stockdale, R., \& Nurdin, N. (2014). THE DEPENDENT VARIABLE IN SOCIAL MEDIA USE [Article]. Journal of Computer Information Systems, 54(2), 25-34. http://ezproxy.lib.swin.edu.au/login?url=http://search.ebscohost.com/login.aspx?direct=true\&db=bth\&AN=94768994\&site=ehostlive\&scope =site

[53] Selviana. (2016). Media Sosial Dalam Perspektif Psikologi. Buletin KPIN, 2(11), 23-45.

[54] Sembiring, S. (2018). Kominfo : Pengguna Internet di Indonesia 63 Juta Orang https://kominfo.go.id/index.php/content/detail/3415/Kominfo+\%3A+Pengguna+Internet+di+Indonesia+63+Juta+Orang/0/berita_satker

[55] Stollfuß, S. (2020). Communitainment on Instagram: Fitness Content and Community-Driven Communication as Social Media Entertainment. SAGE Open, 10(2), 2158244020919535. https://doi.org/10.1177/2158244020919535

[56] Taylor, D. G., \& Strutton, D. (2016). Does Facebook usage lead to conspicuous consumption? Journal of Research in Interactive Marketing, 10(3), 231-248. https://doi.org/10.1108/JRIM-01-2015-0009

[57] Whiting, A., \& Williams, D. (2013). Why people use social media: a uses and gratifications approach. Qualitative Market Research: An International Journal, 16(4), 362-369. https://doi.org/10.1108/QMR-06-2013-0041

[58] Yang, K., \& Banamah, A. (2014). Quota Sampling as an Alternative to Probability Sampling? An Experimental Study. Sociological research online, 19(1), 56-66. https://doi.org/10.5153/sro.3199 